\title{
Research and Practice on graduation Design Reform of Engineering Management major in application-oriented universities
}

\author{
XinxinZhang ${ }^{1}$ \\ ${ }^{1}$ Xi'an Fanyi University Xi'an China
}

\begin{abstract}
Graduation design is the last important link before college students graduate. Referring to the reform and innovation measures of applied talents at home and abroad,this paper analyzes the problems and deficiencies of the current graduation design mode of engineering management specialty.Based on the training mode of applied talents, this paper puts forward some measures for graduation design reform and carries them out. Finally, this paper analyzes the achievements and existing problems of the reform.
\end{abstract}

\section{Introduction}

Engineering management major is compound disciplines at the intersection of engineering and management,this major trains senior management talents with technical,economic management and legal skills,students are required to be able to manage engineering projects after graduation.Graduation design, as the last link in the four years of college, is an extremely important practical teaching link.It is the comprehensive application and test of the knowledge students have learned in the four years of college.It plays an irreplaceable role in the employment of students in the future, and it is also the practical training before graduation.

At present, the reform and practice of graduation design have been carried out competitively in the engineering management major of various universities,and good results have been achieved.Chen Wei etc.from Wuhan University of Technology conducted a study on the graduation design mode of engineering management major based on the cultivation of collaborative ability,and put forward concepts such as collaborative task topic selection collaborative design and double group collaborative mechanism, which improved the practical ability and comprehensive quality of graduates[1]. Pan Jenny from Liaocheng University and others conducted the research on the management of graduation project topic selection in engineering management major of application-oriented undergraduate universities and put forward the countermeasures and Suggestions for graduation project topic selection[2].Li Shirong and others from Chongqing University carried out the BIM based graduation design reform of engineering management major,and provided suggestions for the BIM graduation design reform of domestic universities[3]. Zhou Xian from Changsha University of Science and Technology studied the key problems and countermeasures of graduation design of engineering management major,improved the quality of graduation design of engineering management major through reform, and promoted the employability of students[4].Chen Qian from Heilongjiang Institute of Engineering and others conducted a research on the reform of graduation design of engineering management specialty based on engineering education certification, and put forward specific measures for the reform[5].Wang Wenjing of Shandong University of Technology and others conducted a discussion on the graduation design of engineering management major based on BIM design contest. Combined with BIM design contest, they conducted comprehensive training for students, which enhanced their enthusiasm and interest in learning and improved the quality of graduation design[6].It can be seen from the above that the reform of graduation design is a very important step to improve students' practical ability,and the reform of application-oriented undergraduate colleges is an urgent problem to be solved.Based on the requirements of application-oriented talent training and the actual situation of students, this paper explores the reform of application-oriented college graduation design,which is suitable for the development needs of our university students. 


\section{Problems existing in graduation project of engineering Management major}

\subsection{Graduation project topic is single and not closely combined with the actual project}

Table1. Traditional topic selection in engineering management

\begin{tabular}{|c|c|}
\hline Topic type & $\begin{array}{c}\text { The major specialized courses } \\
\text { involved }\end{array}$ \\
\hline \multirow{2}{*}{$\begin{array}{l}\text { construction organization } \\
\text { plan }\end{array}$} & engineering construction technology \\
\hline & project management \\
\hline \multirow{2}{*}{ valuation with bill quantity } & Quanta application software \\
\hline & measurement and valuation \\
\hline \multirow{2}{*}{ bidding documents } & engineering bidding \\
\hline & measurement and valuation \\
\hline \multirow{2}{*}{ project feasibility study } & project investment and financing \\
\hline & engineering economy \\
\hline
\end{tabular}

The career orientation of engineering management major mainly includes two directions:project management and project cost; the graduation design topic selection is mainly selected by the graduation design instructor.Due to resources and other reasons, the graduation design topic selection cannot be updated according to the needs of the actual project maintaining the integrity of the specifications.In addition, students do not actively pay attention to graduation design, and some students have gone out of school for internships or busy with job interviews, etc. When doing graduation design, there will be a perfunctory phenomenon,making the quality of graduation design is not high.

\subsection{The content of graduation design lacks innovation}

As for the graduation design topics listed in Table 1, students cannot combine their own actual projects in the completion process, and they cannot answer the questions raised by teachers in combination with the reality due to the reference of other students.In construction organization design in the selected topic,for example, the cast-in-place reinforced concrete structure and the prefabricated reinforced concrete structure, the majority of students can't distinguish according to learn professional knowledge in the construction organization design differences,not apply what they have learned professional knowledge,the two kinds of different construction methods of the construction organization design of construction plan for a form.For another example,for the preparation of engineering bidding projects, the template is generally given by the instructor,and students fill in the blanks according to the habit of filling in the blanks.Students do not actively think in the completion of graduation design,but mechanically complete the missing content.

\subsection{The instructor of graduation project is inexperienced}

Due to the large number of students under the guidance of teachers, in addition to the heavy teaching and scientific research tasks, teachers will be powerless in the process of guidance; most teachers walk from one university campus to another with strong professional competence, but lack practical engineering experience and narrow research direction. Therefore, the content of graduation design often cannot be connected with engineering practice, and the topic selection of graduation design is not updated according to the development and needs of construction technology.

\subsection{Students read the references perfunctorily, the time planning is not reasonable}

Before writing the graduation design,the references downloaded by students are not reasonable enough,and they often just read some relatively simple journal papers, without in-depth analysis of the bachelor's degree and higher-level graduation papers.In addition,some students have unreasonable time planning.Most of them are busy with work and do not make full use of their time to write papers. They just blindly rush papers before the teacher urges them to hand in papers, which is of poor quality.

\subsection{The graduation project format is not standard}

Although the students have learned the operation methods of relevant OFFICE software in the course of general education, some students' graduation design format is in a mess, which requires teachers to modify the format repeatedly. This undoubtedly increases teachers' workload, and it is easy to ignore the content problems of graduation design.

\section{The specific method of graduation design reform}

Applied undergraduate graduation design process is a very complicated system engineering, it relates to the enterprises and institutions all aspects such as college students, therefore,the cultivation of applied undergraduate, theory with practice of basic training for engineers is one of the most important link, especially the quality of graduation design is often to measure achievement of students in higher education teaching effectiveness and the level of applied colleges a evaluation index in view of the above problems,applied colleges undergraduate graduation design reform embargo.It is necessary to reform the graduation design of applicationoriented universities,so as to improve the quality of undergraduate graduation design of application-oriented universities and cultivate the talents needed to serve the local economic and social development.

\subsection{Introduce the tutorial system}

In junior or senior students, the students undertake choosing according to the research direction of the guidance teacher mentor,gradually cultivate students 
interest in learning professional knowledge and methods, encourage students to participate in the various disciplines race contest of college students' innovative undertaking,formed by good students and junior students interest in learning team,helping the underachiever professional course of study. Teachers should pay attention to arrange some homework related to the operation method of OFFICE software,so as to lay a preliminary foundation for the future graduation design writing.

\subsection{Hold on-campus trials for various discipline competitions}

Now for the national project management within the scope of the project cost more influential series,such as BIM visionbank calculate quantity competition of competition bidding contest, are in colleges and universities related, but the number is less,so at the beginning of the selection can be a mobilization meeting,employee training organization is interested in participating students,combined with the related countries after the competition format at the school,set up a second prizes,to give students awards and certificates, let more students understand the results of hard work.From the selection of excellent players to participate in the national competition.

\subsection{Hold the graduation project mobilization meeting}

In the preparation stage of graduation design,hold a mobilization meeting,so that students fully realize the importance of graduation design,correct students' attitude.In combination with students' interests and future work direction, teachers and students two-way determine graduation design topic selection, encourage students to combine their own strengths and the direction of the project.It can also be combined with the specific content of the graduation practice to write,by the enterprise and teachers joint evaluation of the final score; according to the principle of combining theory with practice and teaching students according to their aptitude, it is better to select the topic with engineering examples.

\subsection{The graduation project implements the whole process management}

Topic selection is determined by the teachers to guide students to download selected topic related references and books,to read through the collection of paper,write a literature review.It can be seen from the literature review of student's understanding of reference literature review of qualified after writing the opening report,to strengthen the reading of the paper quality controls the opening report from the paper emphatically utlines.In writing papers,the teachers communicated with students in a timely manner,paid attention to strengthening the management of backward students, communicated and contacted with the instructor in time when problems occurred,and paid attention to strengthening the supervision and supervision of students from multiple perspectives.

\subsection{Encourage modern means of information}

Based on BIM technology in engineering application and advantage in today's world,the BIM software is widely used in engineering,there are a small number of students combined with BIM software to carry on the writing of the graduation design, but on the whole design of the students that is shallow and superficial,not really write the graduation design should have the depth and difficulty. The main reason is that most teachers do not have a deep understanding of BIM software, and they need the enterprise engineers to guide the students' project.Schools should also send teachers to enterprises for learning and training,encourage teachers to obtain BIM teacher certificates, and appropriately add BIM technology-related courses when revising talent training programs.

\subsection{The examination method reform of graduation thesis achievement}

At present,the performance of graduation design is mainly composed of three parts: the instructor's evaluation of the teacher and the defense.This kind of assessment method often presents the problem that the performance is not in direct proportion to the performance.Through the reform of performance appraisal,pay attention to the students in the process of writing papers and writing attitude, not to turn in the paper as the main basis to determine the student's final grade each student's graduation design through the opening in the early check strict test,the intermediate inspection reply such as link to guarantee the smooth completion of student papers in the defense,defense team set and checks on the graduation of the students,to strict censorship of rejoin qualification, does not conform to the plea of modified until the accords with a condition to allow defense defense based on the principle of fair and open,ensure that defense process of precise specifications.

\subsection{To guide the cultivation of teachers}

At present,some schools have established the cooperation between colleges and the cultivation of the cooperative education model, but the university-enterprise cooperation is often just surface,not really achieve the purpose of cooperation between colleges and level in guiding graduation thesis, teachers form a group of the same subject,try to introduce practice experienced business mentor to guide every student group introduce at least one enterprise engineers to guide teachers organize summer and winter vacations in the teacher to the corporate credentials the exercise and in-depth study, efforts to improve the teachers' practice ability and level,to train double type teachers.

\subsection{Teachers experience reflection and exchange}

Every teacher has his or her own experience in guiding students, and different problems may arise in guiding students. In particular,many uncontrollable factors may occur in students' off-campus internships.At least the 
instructor of the same research group should hold the experience exchange meeting of graduation design regularly, analyze the common problems of students, especially in the professional knowledge, and feedback the problems to the teachers who undertake the corresponding courses, which can be avoided and improved in the teaching process in the future.

\section{The effect of graduation project reform}

Through the teaching reform, the quality of students' graduation project has been improved obviously, the quality of other aspects has been improved, and the ability of teachers has also been improved.

\subsection{The improvement of students' professional ability}

The author also realized the important position of graduation design in the whole university career and future work.In the process of graduation study,we further strengthened the relevant professional courses,such as engineering measurement and pricing,project management, civil engineering construction technology,engineering bidding and contract management, and so on.At the same time,we can skillfully operate Guanglianda calculation software, architectural CAD, office and other necessary software in future work,which is no longer paper Shangtan Bing can integrate theory with practice and lay a good foundation for practical application in future work.

\subsection{Improvement of other abilities of students}

Some students choose experiments in mechanics and materials according to their own advantages, which not only improves their practical operation ability,but also strengthens their team cooperation ability.In writing papers, they find appropriate methods to deal with data,see their own shortcomings and problems, and find out the methods to deal with problems through learning. These are all in class learning we can't realize that success is also a valuable asset in the future.Through the reform,the students' comprehensive practical ability,flexible use of the knowledge they have learned, the ability to analyze and solve problems, the comprehensive quality and innovation ability have been improved, which plays an irreplaceable role.

\subsection{The improvement of teachers' ability}

Although after the graduation project teaching reform,the task of teachers is more onerous, but teachers also have some gains in the reform. The enthusiasm of students makes teachers have a sense of achievement and mission. They no longer regard being a tutor as a task to complete, but enjoy the process of guidance.Through the reform of graduation project,the instructor strengthened the communication and communication with students,more understanding of students' ideas,understanding of students' needs and shortcomings, which can provide a certain basis for future teaching and curriculum reform, and find the direction of curriculum reform in the future.In addition,through the teaching reform of graduation project,it has played a good role in promoting the construction of study style,teachers' ethics and strict management of learning,and has also played a warning role in the learning of lower grade students. We should be more active and work hard in the later classroom.

\section{Conclusion}

Although through the above teaching reform, the comprehensive quality of students has been significantly improved, there are still some questions.

Firstly, in the school enterprise cooperation, it needs the strong support of the school and various majors, which can not be accomplished by teachers of a certain department or a certain specialty, which needs to reach a consensus with the senior leaders of the school.

Secondly, the students' thesis writing is only the work of guiding teachers, but also needs the communication and cooperation between the teachers and the learning management department, so that the learning management department can also join in this work, which can give students better guidance and supervision.

Third, for the cultivation of double qualified teachers, schools need to formulate corresponding policies to encourage teachers to go out for training and learning.

Fourth, whether it is school enterprise cooperation or the purchase of learning software, schools need financial support.

If you want to better complete the content of the whole graduation project,it can't be completed overnight. This is the reflection of students' good knowledge reserve in the four years of University.Students need to strengthen the flexible use of knowledge and the ability to comprehensively analyze and solve problems in the course of learning.Therefore, only the reform of graduation design can not fully achieve the application.In order to achieve the training objectives and requirements of applied talents,all teachers should carefully analyze their own courses and carry out corresponding teaching reform.

In short, through the reform of the graduation project, it has played a good role in promoting the quality of personnel training of engineering management specialty, better serving the development of local economy, and providing certain reference experience for the teaching reform of other majors.

\section{Acknowledgement}

I would like to express my sincere thanks to the schoollevel experiment teaching demonstration center and virtual simulation experiment teaching center program of Xi'an FanYi University in 2019, "Engineering Management Experimental Teaching Demonstration Center" (Z1901) for their financial support for this paper. 


\section{References}

1. Chen Wei, Yi Sha, et al. Research on graduation Design Model of Engineering Management Major based on Collaborative Ability Training [J]. Higher architectural Education.2016,26(1) :168-173.

2. Pan Janie, Chen Xia. Management research on graduation Project Of Engineering Management major in application-oriented universities [J]. Value engineering.2017, (36) :206-208.

3. Li Shirong, Wu Chengke, Li Xiao, Chen Xia. BIM based Graduate Design Reform of Engineering Management Major -- A Case Study of Chongqing University [J].Engineering economy.2016, 26(8) :5761

4. Zhou Xian, Peng Junlong. Research on key Problems and Countermeasures of graduation Design of Engineering Management Major $[\mathrm{J}]$. Subject to explore .2017, (6) :33-34,42.

5. Chen Qian, NIU Zhe. Research on graduation Design Reform of Engineering Management Major based on Engineering Education Certification in Heilongjiang Institute of Engineering [J]. Intelligence,2016:11.

6. Wang Wenjing, Zhang Yong. Discussion on graduation Design of Engineering Management Major based on BIM Graduation Design Competition [J]. Intelligence, 2018:164. 